\title{
Synthesis and Pharmacology of 6-Substituted Benztropines: Discovery of Novel Dopamine Uptake Inhibitors Possessing Low Binding Affinity to the Dopamine Transporter
}

\author{
Daniele Simoni, ${ }^{*}, \dagger$ Marcello Rossi, ${ }^{\dagger}$ Valerio Bertolasi, ${ }^{\S}$ Marinella Roberti,$\perp$ Daniela Pizzirani,,$\perp$ \\ Riccardo Rondanin, ${ }^{\dagger}$ Riccardo Baruchello, ${ }^{\dagger}$ Francesco Paolo Invidiata, ${ }^{\ddagger}$ Manlio Tolomeo, ${ }^{\otimes}$ Stefania Grimaudo, ${ }^{\otimes}$ \\ Stefania Merighi," Katia Varani," Stefania Gessi," Pier Andrea Borea," Silvia Marino," Sabrina Cavallini," \\ Clementina Bianchi," and Anna Siniscalchi" \\ Dipartimento di Scienze Farmaceutiche, Università di Ferrara, Via Fossato di Mortara 17-19, 44100 Ferrara, Italy, \\ Dipartimento di Chimica, Università di Ferrara, Dipartimento di Scienze Farmaceutiche, Università di Bologna, \\ Dipartimento Farmacochimico Tossicologico e Biologico, Università di Palermo, Divisione di Ematologia e Servizio A.I.D.S., \\ Policlinico, Università di Palermo, Italy, and Dipartimento di Medicina Clinica e Sperimentale, Sezione di Farmacologia, \\ Università di Ferrara, Italy
}

Received December 1, 2004

A series of $6 \alpha$ - and $6 \beta$-substituted benztropines were synthesized. A marked enantioselectivity was observed for the $6 \beta$-methoxylated benztropines, the $(1 R)$-isomers being more potent than the corresponding $(1 S)$ compounds. The racemic $6 \alpha$-methoxy-3-(4',4"-difluorodiphenylmethoxy)tropane (5g) was the most potent compound. It has been found that modifications at the 6-position of benztropine might reduce the DAT binding affinity, maintaining otherwise a significant dopamine uptake inhibitory activity. A reinvestigation of the absolute configuration of $6 \beta$-methoxytropinone proved the $6 R$ configuration for the (+)-enantiomer.

\section{Introduction}

Cocaine (1) is a potent stimulant of the central nervous system, and its widespread abuse has an extremely negative impact in our society. The development of therapeutic agents that will assist addicted individuals during detoxification programs is therefore particularly desirable.

Cocaine is a nonselective drug that interacts with a variety of pharmacologically distinct sites. It binds with high affinity to the transporter sites for the neurotransmitters dopamine (DA), serotonin (5-hydroxytryptamine, 5 -HT), and noradrenaline (NA), thereby inhibiting the reuptake of these amines into the presynaptic neurons. ${ }^{1-4}$ Since the dopamine transporter (DAT) is considered to be the main target of the biochemical action of cocaine as well as of its behavioral effects, many intervention strategies have focused on the dopaminergic pathway. ${ }^{1-6}$

The search for potential anti-cocaine medications has led to an extensive study of the structure-activity relationships (SAR) of $\mathbf{1}$ at the dopamine transporter, and 2-substituted 3-aryltropanes have been extensively studied as cocaine congeners and developed as tools to explore the DAT.1,2,6 This broad class of compounds has provided interesting insight into the nature of the dopamine transporter pharmacophore. . $^{1,2,6}$ Additionally, 6 - and 7-substituted tropanes have been widely inves-

* To whom correspondence should be addressed. Tel.: +39-0532291291. Fax: +39-0532-219296. E-mail: smd@dns.unife.it.

$\dagger$ Dipartimento di Scienze Farmaceutiche, Università di Ferrara.

$\S$ Dipartimento di Chimica, Università di Ferrara.

$\perp$ Dipartimento di Scienze Farmaceutiche, Università di Bologna.

¥ Dipartimento Farmacochimico Tossicologico e Biologico, Università di Palermo.

${ }^{\otimes}$ Divisione di Ematologia e Servizio A.I.D.S., Policlinico, Università di Palermo.

"Dipartimento di Medicina Clinica e Sperimentale, Sezione di Farmacologia, Università di Ferrara. tigated in order to discover appropriate molecular modifications that may lead to the discovery of cocaine antagonists or partial agonists. ${ }^{7-13}$

Among the structural classes of compounds interacting with DAT, which have provided interesting results as potential medications to treat cocaine abuse, the benztropine group has also received particular attention. ${ }^{5,6}$ The introduction of a 2-carbomethoxy group into benztropine (2) by Meltzer ${ }^{14}$ et al. resulted in a new class of compounds with the $(1 S)$ derivative exhibiting significant DAT affinity and the most potent representative being difluoropine (4). Hydroxylation at the 6-7 positions of difluoropine, produced, on the contrary, a significant decrease in binding affinity. ${ }^{7}$ Meltzer et al. have hypothesized that this class of dopamine uptake inhibitors are more like the GBR series in their mode of binding to the DAT. ${ }^{15}$ Benztropine is an anticholinergic DAT inhibitor, equipotent to cocaine, which is clinically used for the treatment of movement disorders that accompany Parkinson's disease. Structurally, benztropine possesses a tropane ring, as found in cocaine, and a diphenylmethane ether group, as found in the GBR series. ${ }^{16}$ Drug design strategies have focused mainly on the substitution pattern in the aromatic moiety and the replacement of the $N$-methyl group by other substituents. ${ }^{5,17-20}$ Unlike cocaine, the benztropine analogues, despite their high affinity for the DAT, generally have not demonstrated a cocaine-like behavioral profile in animal models. After considerable research in this area, Newman and co-workers have hypothesized that this class of dopamine uptake inhibitors may access a DAT binding site distinct from that of cocaine, so explaining their discrepant behavioral profile. ${ }^{5,17}$ In preclinical studies aimed at gauging its possible use in the treatment of cocaine abuse, $4^{\prime}, 4^{\prime \prime}$ - 

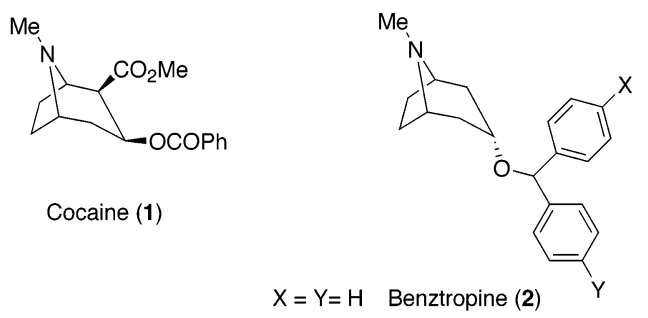

Cocaine (1)

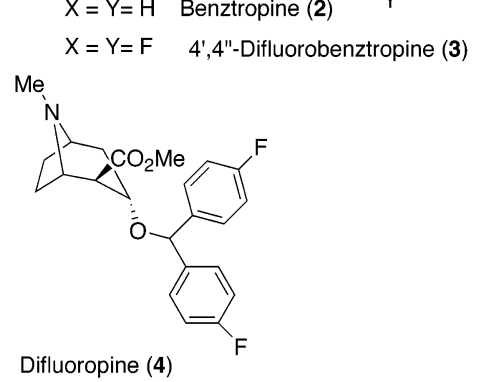

Figure 1. Structures of cocaine, benztropine, and analogues.

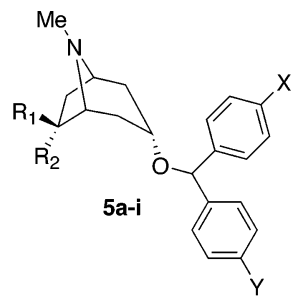

$R_{1}, R_{2}=$ Oxygenated Moieties

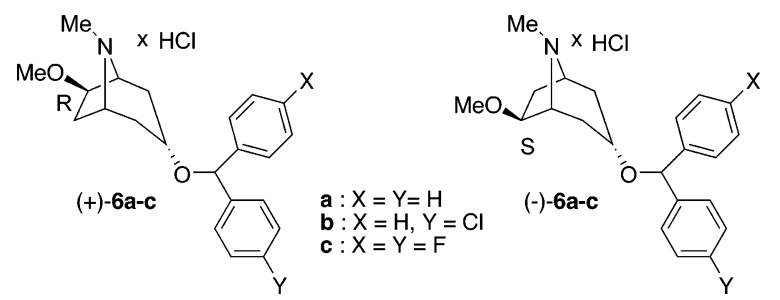

Figure 2. General structure of benztropines synthesized for SAR studies.

difluorobenztropine (3) has shown some promise in the attenuation of cocaine effects in animal studies. ${ }^{21}$

We have recently undertaken a structural investigation at the two-carbon bridge region of benztropine, and we communicated that $6 \beta$-methoxy- $4^{\prime}, 4^{\prime \prime}$-difluoro- and $-4^{\prime}$-chlorobenztropine possess high binding affinity $\left(\mathrm{IC}_{50}\right.$ $=25-32 \mathrm{nM})$ to DAT, as compared to benztropine $\left(\mathrm{IC}_{50}\right.$ $=118 \mathrm{nM})$ and cocaine $\left(\mathrm{IC}_{50}=150 \mathrm{nM}\right)$, when evaluated under identical assay conditions. ${ }^{22}$ Herein, we report the synthesis and pharmacological characterization of a novel series of 6 -substituted benztropines $\mathbf{5 a}-\mathbf{i}$ (Figure 2 , Schemes 2, 3) and the 6-benzhydrylated tropanes $\mathbf{2 4}$ and 25 (Scheme 4). We also report the full details of the synthesis and biological activity of our previously communicated 6-methoxybenztropines (+)-6a-c and $(-)-\mathbf{6 a}-\mathbf{c}$ (Figure 2). ${ }^{22}$ A reinvestigation of the absolute configuration of the (+)- and (-)-6 $\beta$-methoxytropinone will be also discussed.

The $6 \beta$-hydroxy-4',4"-difluorobenztropine ( \pm )-5c demonstrated a profile of activity similar to the parent $4^{\prime}, 4^{\prime \prime}$ difluorobenztropine (3). ${ }^{19}$ Some of the novel synthesized benztropines showed together a reduction of DAT binding affinity a concomitant improvement of the dopamine uptake inhibitory activity. The present paper provides further support that, despite structural commonalties
Scheme 1. Chemical Resolution of the $( \pm)-6 \beta$-Methoxytropinone (7) and Synthesis of Chiral $6 \beta$-Methoxylated Benztropines ${ }^{a}$

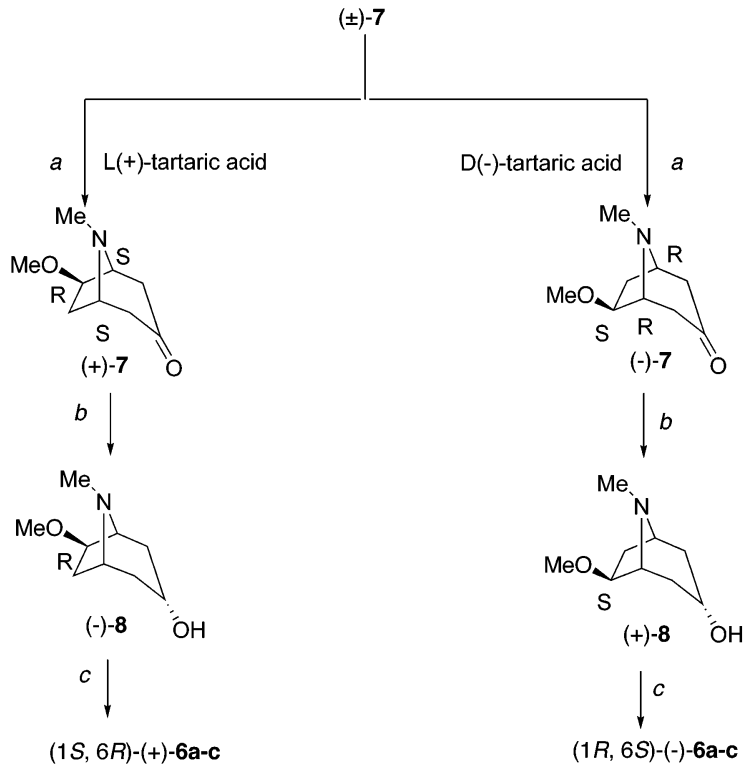

${ }^{a}$ Reagents and conditions: (a) $90 \% \mathrm{EtOH}, 50{ }^{\circ} \mathrm{C}$; (b) $\mathrm{PtO}_{2}, \mathrm{H}_{2}$, absol EtOH, 70 psi, 14 h; (c) x,y-benzhydrol, $p$-TsOH monohydrate, benzene, reflux, $24 \mathrm{~h}$.

between dopamine uptake inhibitors, a common binding domain may not be accessed by all of these compounds.

Chemistry. Regarding the synthesis of stereoisomers $(+)-\mathbf{6 a}-\mathbf{c}$ and $(-)-\mathbf{6 a}-\mathbf{c}$, we considered, as previously communicated, ${ }^{22}$ that the chiral methoxytropinones $(+)-7$ and (-)-7, possessing the known configuration at the carbon atom bearing the methoxy functionality, would constitute appropriate starting materials for their preparation (Scheme 1). Previous investigations had indicated the $6 S$ configuration of the $(+)-6 \beta$-methoxytropinone. ${ }^{23}$ Consequently, we referred to literature indications to assign, incorrectly, stereochemistry in our communications. ${ }^{12,22}$ In contrast, we have now proved unequivocally that $(+)-\mathbf{6 a}-\mathbf{c}$ and their synthetic precursor (+)-6 $\beta$-methoxytropinone (+)-7 are actually $6 R$ as detailed below. Briefly, the (-)-6 $\beta$-methoxytropinone $(-)-(7)$ was obtained from the racemic $( \pm)-\mathbf{7}$ when $\mathrm{D}(-)$-tartaric acid was used for the resolution and (+)$6 \beta$-methoxytropinone $(+)-(7)$ was obtained utilizing the $\mathrm{L}(+)$-tartaric acid. Sodium borohydride reduction of $(+)-\mathbf{7}$ gave a mixture of the two alcohols $(-)-\mathbf{8}$ and (-)-9 that were each esterified with $\left(1^{\prime} S\right)-(-)$-camphanic chloride to obtain the pure diastereoisomers $(-)-\mathbf{1 0}$ and $(+)-11$ respectively (Figure 3$)$. The absolute configuration of $(-)-\mathbf{1 0}$ (suitable crystals of $(+)-\mathbf{1 1}$ could not be obtained by these means), determined by X-ray crystallographic analyses, confirmed the $R$ configuration at C6 (Figure 4). Consequently, the $6 R$ configuration was also attributed to the precursor (+)-7, and the $6 S$ configuration was assigned to the enantiomer (-)-7.

In the following step (Scheme 1), the stereoselective reduction $\left(\mathrm{H}_{2}\right.$ and $\mathrm{PtO}_{2}$ as catalyst) of the ketones (+)-7 and (-)-7 produced the corresponding alcohols derivatives (-)-8 and (+)-8 in optically pure form. These were reacted with the appropriate benzhydrols in the presence of $p$-toluenesulfonic acid and refluxed with a 


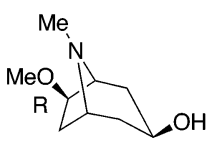

$(-)-9$

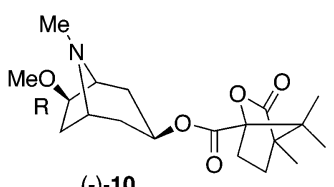

$(-)-10$

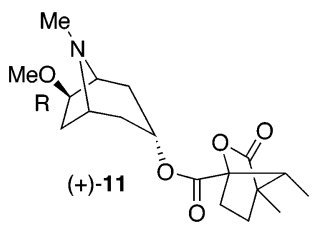

Figure 3. Camphanic derivatives and synthetic precursor.

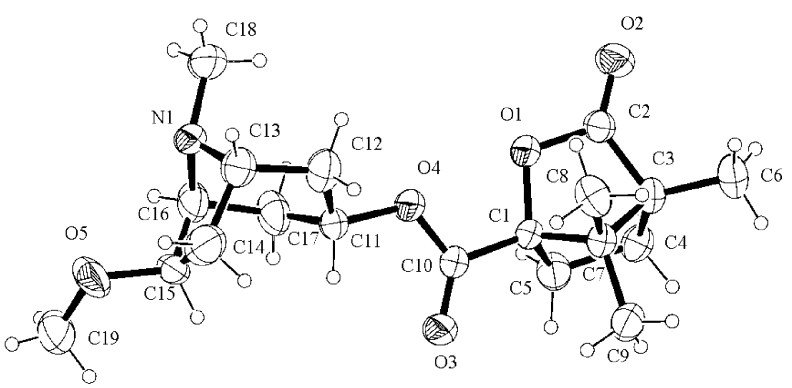

Figure 4. ORTEP view of compound (-)-10 displaying the thermal ellipsoids at $30 \%$ probability.

Dean-Stark apparatus to afford, in appreciable yields, the desired chiral benztropines $(+)-\mathbf{6 a}-\mathbf{c}$ and $(-)-\mathbf{6 a}-$ c.

Preparation of the hydroxylated racemic benztropines $\mathbf{5 a}-\mathbf{c}$ is outlined in Scheme 2. The racemic hydroxytropinone 12 was methoxymethylated with dimethoxymethane in the presence of $4 \AA$ molecular sieves and with $p$-toluenesulfonic acid as catalyst to give $\mathbf{1 3}$ in $62 \%$ yield. The stereoselective reduction of $\mathbf{1 3}$ by means of hydrogen and $\mathrm{PtO}_{2}$ as catalyst at 50 psi produced in $88 \%$ yield the tropine derivative $\mathbf{1 4}$ which was reacted with the appropriate benzhydryl chlorides in the presence of tributylamine and refluxed for $8 \mathrm{~h}$ in dry dimethylformamide to afford the MOM-protected benztropines $\mathbf{5 a -}$ c. Conversion of the latter into racemic $\mathbf{5 d - f}$ was achieved by treatment with a $10 \% \mathrm{HCl}-\mathrm{MeOH}$ solution at $65{ }^{\circ} \mathrm{C}$.

The synthesis of the $6 \alpha$-substituted tropinones $( \pm)-$ $\mathbf{5 g}-\mathbf{i}$ is outlined in Scheme 3. The ketone derivative 15 was reduced with DIBAL-H in dichloromethane solution to give the $6 \alpha$-hydroxy derivative $\mathbf{1 6}$ and then hydrolyzed with $10 \% \mathrm{HCl}$ to produce the $6 \alpha$-hydroxytropinone 17. As described above for the MOM-derivative 13, the hydroxytropinone $\mathbf{1 7}$ was easily methoxymethylated to give the MOM-protected derivative 18. The stereoselective reduction of the racemic tropinones $\mathbf{1 8}$ and $\mathbf{1 9}$ (Scheme 3) by means of hydrogen and $\mathrm{PtO}_{2}$ produced, in approximately $90 \%$ yield, the tropines $\mathbf{2 0 a}, \mathbf{b}$. Reduction of 18 and 19 was also achieved by means of $\mathrm{NaBH}_{4}$, which produced $\mathbf{2 0 a}, \mathbf{b}$ as the only isomers. Tropines $\mathbf{2 0 a}, \mathbf{b}$ were reacted as described above for (-)-8 and 14, to give in appreciable yields the desired $( \pm)-\mathbf{5 g}, \mathbf{h}$. Exposure of $\mathbf{5 h}$ to a solution of $10 \% \mathrm{HCl}-\mathrm{MeOH}$ at 65 ${ }^{\circ} \mathrm{C}$ gave $( \pm)-\mathbf{5 i}$ in $40 \%$ yield.

The $6 \alpha$ - and $6 \beta$-( $4^{\prime}, 4^{\prime \prime}$-difluorodiphenylmethoxy)tropanes ( \pm -24 and ( \pm -25 were prepared as outlined in Scheme 4. Inversion of the bridge hydroxyl group of 21, in turn obtained by reduction of ( \pm )-12 under Wolff-
Kishner conditions, was effected in two steps by Mitsunobu chemistry. Thus, the $6 \beta$-hydroxy derivative $\mathbf{2 1}$ was reacted with $p$-nitrobenzoic acid and triphenylphosphine in the presence of diethyl azodicarboxylate to give the ester intermediate 22, which was in turn hydrolyzed with $\mathrm{LiOH} / \mathrm{THF} / \mathrm{H}_{2} \mathrm{O}$ to provide the $6 \alpha$-hydroxy analogue 23. Finally, the benzhydryl derivatives $( \pm)-24$ and ( \pm )-25 were obtained as described above for $\mathbf{5 g}, \mathbf{h}$.

\section{Biological Results and Discussion}

Binding affinities of all novel synthesized compounds were evaluated in radiolabeled ligand displacement assays for DAT in the brain. Compounds were examined for their ability to displace $\left[{ }^{3} \mathrm{H}\right]$ WIN 35,428 and $\left[{ }^{3} \mathrm{H}\right]$ paroxetine from the dopamine and serotonin transporters in rat caudate putamen. Additionally, all compounds were tested for their ability to inhibit high-affinity uptake of $\left[{ }^{3} \mathrm{H}\right]$ dopamine into striatal nerve endings (synaptosomes). Biological data are reported in Table 1. There was a good correlation between uptake inhibition and binding values $(r=0.949, P<0.001)$, as shown in Figure 5.

The enantiomers $(1 S, 6 R)-(+)-\mathbf{6 a}-\mathbf{c}$ and $(1 R, 6 S)-(-)-$ $\mathbf{6 a}-\mathbf{c}$ were prepared to investigate whether stereochemistry could play a role in binding and uptake activity of chiral benztropines. In general, the $6 \beta$-methoxylated chiral benztropines retain activity relative to their parent structures, benztropine and cocaine, in both binding and functional assays (Table 1). The enantiomers (-)-6a-c, bearing the (1R)-configuration, were more potent than the corresponding $(1 S)$ stereoisomers $(+)-6 a-c$. All the newly synthesized methoxylated benztropines lacked SERT activity. In particular, a marked enantioselectivity is seen for (-)-6b being 23 times more potent than $(+)-\mathbf{6 b}$. Thus, while a 2-carbalkoxy-benztropine series showed a strong biological preference for the $(1 S)$-configuration, ${ }^{14,19,20}$ the above-described chiral 6-methoxylated benztropines show preference for the $(1 R)$-configuration.

Interestingly, the ( \pm )-6 $\alpha$-methoxy- $4^{\prime}, 4^{\prime \prime}$-difluorobenztropine $5 \mathrm{~g}$ is the most potent analogue in the reported series of methoxylated benztropines. Unlike the $6 \beta$ methoxylated derivatives, $\mathbf{5} \mathbf{g}$ demonstrates, moreover, a notable binding affinity for SERT. On the contrary, an increased bridge-steric bulk, as in the MOMprotected compounds $\mathbf{5 a - c}$ and $\mathbf{5 h}$, resulted in a reduced binding affinity as compared with the methoxy derivatives.

Remarkable results were obtained when a hydroxyl group was introduced into the benztropine two-carbon bridge. Introduction of functionalities at the cocaine 6,7bridge has attracted the attention of a number of research groups. ${ }^{7-13}$ In general, steric bulk at both positions has reduced the affinity of these compounds for the dopamine transporter, but the 6- or 7-hydroxyl group in 2-carbomethoxy-3-aryltropanes is tolerated when an appropriate substituent is present at the 3-position, with comparable potency and better selectivity for DAT. ${ }^{6,7,9}$ As reported in Table 1, the hydroxylated benztropines $\mathbf{5 d} \mathbf{d}, \mathbf{e}$ demonstrated binding affinities in the micromolar range. It is remarkable that the hydroxylated $4^{\prime}, 4^{\prime \prime}$-difluorobenztropine $\mathbf{5 f}$ and $\mathbf{5} \mathbf{i}^{24}$ showed binding and dopamine uptake activity similar to the parent 3. ${ }^{5}$ Of interest, while the binding affinity of $\mathbf{5 d , e ~ i s ~}$ 
Scheme 2. Synthesis of $6 \beta$-Hydroxylated Benztropines ${ }^{a}$

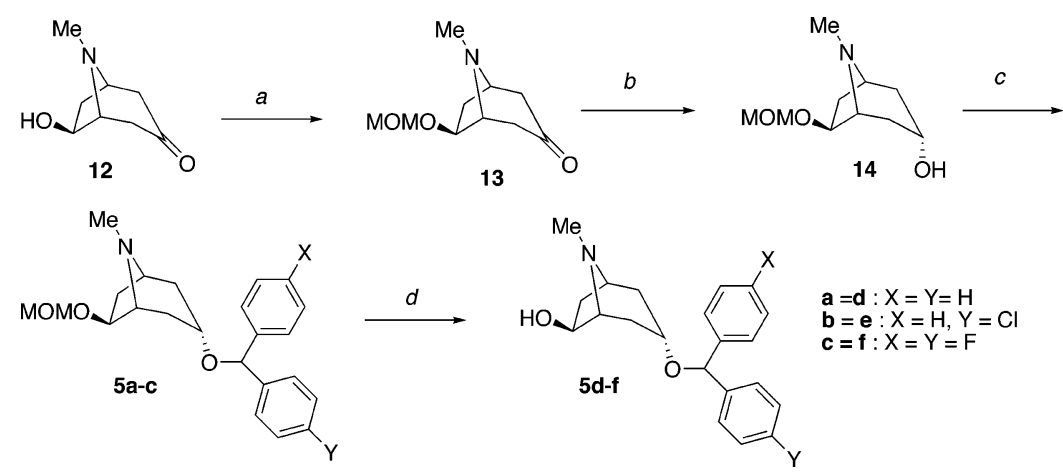

${ }^{a}$ Reagents and conditions: (a) Dimethoxymethane, $\mathrm{CH}_{2} \mathrm{Cl}_{2}, 4 \AA$ molecular sieves, p-TsOH, $40{ }^{\circ} \mathrm{C}$; (b) $\mathrm{PtO} 2, \mathrm{H}_{2}, \mathrm{EtOH}, 40$ psi, $12 \mathrm{~h}$; (c) x,y-benzhydryl chloride, $\mathrm{Bu}_{3} \mathrm{~N}, \mathrm{DMF}, 160{ }^{\circ} \mathrm{C}$; (d) $\mathrm{HCl} 37 \%$, MeOH, $65{ }^{\circ} \mathrm{C}, 3 \mathrm{~h}$.

Scheme 3. Synthesis of $6 \alpha$-Hydroxylated Benztropines ${ }^{a}$
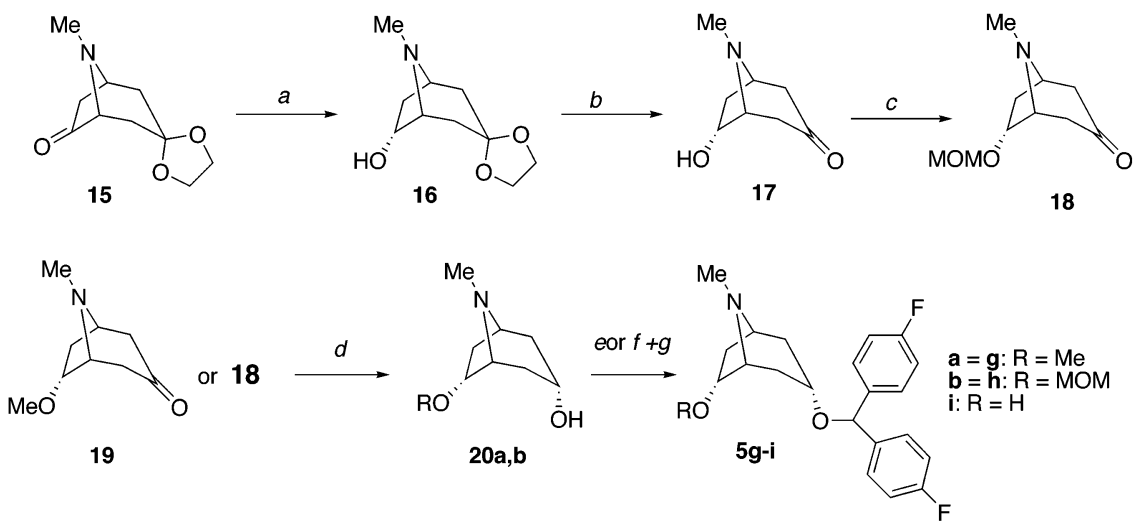

${ }^{a}$ Reagents and conditions: (a) DIBAL- $\mathrm{H}, \mathrm{CH}_{2} \mathrm{Cl}_{2},-78{ }^{\circ} \mathrm{C}$ to $0{ }^{\circ} \mathrm{C}, 1 \mathrm{~h}$; (b) aq $\mathrm{HCl}, \mathrm{MeOH}, 65{ }^{\circ} \mathrm{C}, 10 \mathrm{~h}$; (c) dimethoxymethane, $\mathrm{CH}_{2} \mathrm{Cl}_{2}$, $4 \AA$ Å molecular sieves, p-TsOH, $40^{\circ} \mathrm{C}$; (d) $\mathrm{PtO}_{2}, \mathrm{H}_{2}$, EtOH, $40 \mathrm{psi}, 12 \mathrm{~h}$; (e) 4,4'-difluorobenzhydrol, $p$-TsOH monohydrate, benzene, reflux, $24 \mathrm{~h}$; (f) 4,4'-difluorobenzhydryl chloride, $\mathrm{Bu}_{3} \mathrm{~N}$, DMF, $160{ }^{\circ} \mathrm{C}$; $(\mathrm{g}) 37 \% \mathrm{HCl}, \mathrm{MeOH}, 65{ }^{\circ} \mathrm{C}, 3 \mathrm{~h}$.

Scheme 4. Synthesis of benztropines 24 and $\mathbf{2 5}^{a}$

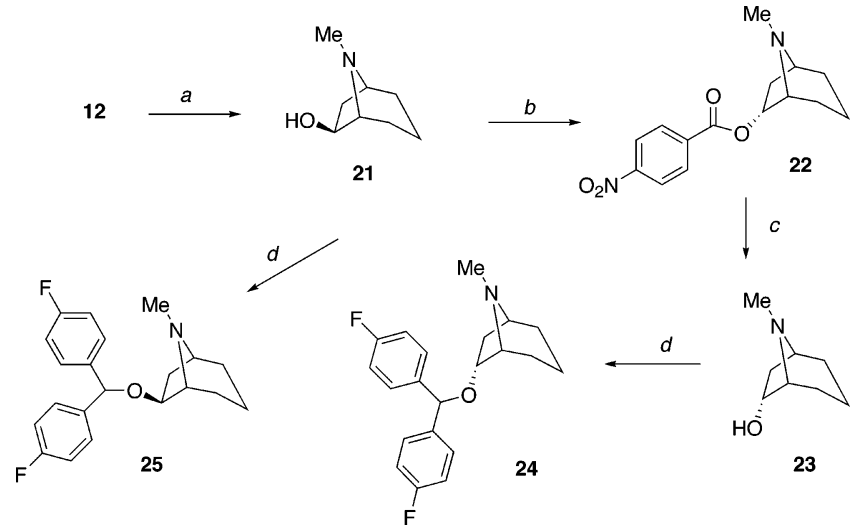

${ }^{a}$ Reagents and conditions: (a) $\mathrm{NH}_{2} \mathrm{NH}_{2} \cdot \mathrm{H}_{2} \mathrm{O}, \mathrm{EtOH}, \mathrm{KOH}, 130$ ${ }^{\circ} \mathrm{C} / 190{ }^{\circ} \mathrm{C}$; (b) DEAD, 4-nitrobenzoic acid, $\mathrm{P}(\mathrm{Ph})_{3}$, toluene, $70{ }^{\circ} \mathrm{C}$. (c) $\mathrm{LiOH} \cdot \mathrm{H}_{2} \mathrm{O}, \mathrm{H}_{2} \mathrm{O}$, THF, rt, $3 \mathrm{~h}$; (d) 4,4'-difluorobenzhydryl chloride, $\mathrm{Bu}_{3} \mathrm{~N}, \mathrm{DMF}, 160{ }^{\circ} \mathrm{C}, 8 \mathrm{~h}$.

considerably diminished in comparison with benztropine, their potency in inhibiting $\left[{ }^{3} \mathrm{H}\right]$ dopamine uptake (DAUI) is higher than cocaine; in fact, their dopamine uptake activity is 7-15 times higher than the binding activity. Contrary to our expectations, the binding activities of $\mathbf{2 4}$ and $\mathbf{2 5}$ were not particularly interesting; however, their uptake activity was also quite surprising, being higher than their binding values. To the best of our knowledge these differences in binding vs DAUI, as found for $\mathbf{5 d}, \mathbf{e} \mathbf{2 4}$, and $\mathbf{2 5}$, have not been previously encountered in benztropine analogues lacking a 2-posi-
Table 1. Binding Affinities and Uptake Inhibition Data for Chiral and Racemic Benztropines

\begin{tabular}{lcll}
\hline \multicolumn{1}{c}{ compd } & $\begin{array}{c}\left.\text { DA[ }{ }^{3} \mathrm{H}\right] \text { WIN 35,428 } \\
\text { binding IC }_{50}(\mathrm{nM})^{a}\end{array}$ & $\begin{array}{c}\left.{ }^{3} \mathrm{H}\right] \mathrm{DA} \text { uptake } \\
\mathrm{IC}_{50}(\mathrm{nM})^{a}\end{array}$ & $\begin{array}{l}5 \mathrm{HT}\left[{ }^{3} \mathrm{H}\right] \text { paroxetine } \\
\text { binding IC }_{50}(\mathrm{nM})^{a}\end{array}$ \\
\hline cocaine & $150 \pm 20$ & $353.1 \pm 36.4$ & $($ citalopram) \\
& & & $0.5 \pm 0.1 \mathrm{nM}$ \\
benztropine & $118 \pm 9$ & $403 \pm 115$ & \\
$( \pm)-\mathbf{5 a}$ & $4500 \pm 600$ & $1083.7 \pm 244.3$ & $>10^{4}$ \\
$( \pm)-\mathbf{5 b}$ & $400 \pm 64$ & $193.7 \pm 38.2$ & $>10^{4}$ \\
$( \pm)-\mathbf{5 c}$ & $340 \pm 70$ & $79.7 \pm 10.8$ & $>10^{4}$ \\
$( \pm)-\mathbf{5 d}$ & $1300 \pm 300$ & $149.4 \pm 7.7$ & $>10^{4}$ \\
$( \pm)-\mathbf{5 e}$ & $600 \pm 85$ & $39.1 \pm 4.6$ & $>10^{4}$ \\
$( \pm)-\mathbf{5 f}$ & $12 \pm 3$ & $8.1 \pm 1.9$ & $11000 \pm 1300$ \\
$( \pm)-\mathbf{5 g}$ & $10 \pm 2$ & $12.4 \pm 1$ & $280 \pm 25$ \\
$( \pm)-\mathbf{5 h}$ & $2500 \pm 300$ & $490.9 \pm 80.5$ & $3500 \pm 400$ \\
$( \pm)-\mathbf{5 i}$ & $140 \pm 25$ & $162.3 \pm 22.8$ & $>10^{4}$ \\
$(1 S)-(+)-\mathbf{6 a}$ & $975 \pm 85$ & $239.7 \pm 23.1$ & $>10^{4}$ \\
$(1 R)-(-)-\mathbf{6 a}$ & $276 \pm 40$ & $138.8 \pm 25.7$ & $>10^{4}$ \\
$(1 S)-(+)-\mathbf{6} \mathbf{b}^{b}$ & $750 \pm 70$ & $519 \pm 29$ & $>10^{4}$ \\
$(1 R)-(-)-6 b^{b}$ & $32 \pm 2$ & $179 \pm 9$ & $>10^{4}$ \\
$(1 S)-(+)-\mathbf{6 c}^{b}$ & $95 \pm 5$ & $165 \pm 10$ & $>10^{4}$ \\
$(1 R)-(-)-6 c^{b}$ & $25 \pm 3$ & $104 \pm 11$ & $>10^{4}$ \\
$( \pm)-\mathbf{2 4}$ & $900 \pm 100$ & $347 \pm 48.5$ & $>10^{4}$ \\
$( \pm)-\mathbf{2 5}$ & $1125 \pm 130$ & $199 \pm 28.8$ & $2000 \pm 200$ \\
\hline
\end{tabular}

${ }^{a}$ Values are expressed as mean $\pm \mathrm{SE}(n=3-9) .{ }^{b}$ Data as reported in ref 22 .

tion substituent. During the course of this work, it was reported that $2 \beta$-carboalkoxy-substituted-(bis[4-fluorophenyl]methoxy)tropanes, unlike the parent $\mathbf{3}$, were more potent in inhibiting dopamine uptake than in binding to the dopamine transporter. ${ }^{19}$ However, these results are quite different from our findings since the 2-carbalkoxy-substituted benztropines possess, unlike the hydroxylated benztropines $\mathbf{5 d}, \mathbf{e}$ and derivatives $\mathbf{2 4}$, 


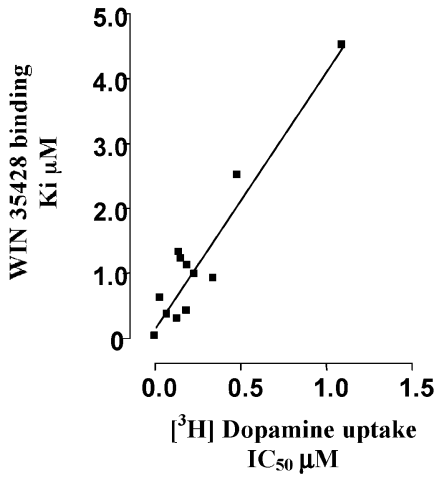

Figure 5. Correlation of $\mathrm{IC}_{50}$ values for $\left[{ }^{3} \mathrm{H}\right]$ dopamine uptake vs $\left[{ }^{3} \mathrm{H}\right]$ WIN35428 binding $K_{\text {i values }}(n=3-9$ determinations per value). Correlation and probability were determined by using Pearson's correlation analysis: $r=0.949$ (95\% confidence interval $0.824-0.986, P<0.001$ ).

25, high binding affinity. Interpretation of these findings is not easy: as hypothesized for the 2-carboalkoxysubstituted benztropines, ${ }^{19}$ the disparity in potency in the functional assay compared to binding constants may be related to assay conditions (e.g. $33{ }^{\circ} \mathrm{C}$ for uptake experiments vs $0{ }^{\circ} \mathrm{C}$ for binding experiments, or different ion concentrations in the buffers) and may be not reflected in vivo.

Thus, the increased potency of the DA uptake inhibition of compounds $\mathbf{5 d , e , ~ 2 4 , ~ a n d ~} \mathbf{2 5}$ suggests that substitution at the bridgehead region of benztropine may provide an interesting opportunity for the construction of new classes of DA-uptake inhibitors with a novel profile of activity.

In summary, bridge-methoxylation of benztropine produced compounds possessing high DAT activity, and the $1 R$ isomers are more potent than the corresponding $1 S$ isomers. Among the results obtained, perhaps the most interesting observation relates to the disparity in DA-uptake potency and binding constants as found for compounds 5d,e, 24, and $\mathbf{2 5}$. We observed that, in some cases, manipulation at the two-carbon bridge region of benztropine significantly altered the biological activity of the compounds, and potent DA-uptake inhibitors, possessing a low binding affinity to the DAT, have been discovered. However, some other compounds retained high activity for both DAT binding and inhibition. Our work is currently continuing in the exploration of other 6,7-bridge-substituted benztropines.

\section{Experimental Section}

Different results from literature data ${ }^{23}$ have been obtained with the following:

Resolution of $( \pm)$-6 $\beta$ - Methoxy-8-methyl-8-aza-bicyclo[3.2.1] octan-3-one (7). The tropinone $7(4.0 \mathrm{~g}, 24 \mathrm{mmol})$ dissolved in $90 \% \mathrm{EtOH}(5 \mathrm{~mL})$ was added dropwise to a hot solution of (-)-D-tartaric acid (3.55 g, $24 \mathrm{mmol}$ ) solubilized in $90 \% \mathrm{EtOH}(25 \mathrm{~mL})$. The crude hydrogen tartrate salt $(3.5 \mathrm{~g})$ was filtered and recrystallized once from $90 \% \mathrm{EtOH}$ and once from $96 \% \mathrm{EtOH}$, to give $(1 R)-6 \beta$-methoxytropinone hydrogen D-tartrate as a white crystalline solid $(2.43 \mathrm{~g}, 7.6 \mathrm{mmol})$ with $\mathrm{mp} 124{ }^{\circ} \mathrm{C}$ (lit. $\left.\mathrm{mp} 128.5-131.5^{\circ} \mathrm{C}\right)^{23}$ and $[\alpha]^{20} \mathrm{D}=-23.6(c=$ $\left.0.5, \mathrm{H}_{2} \mathrm{O}\right)\left[\mathrm{lit}^{23}[\alpha]^{20} \mathrm{D}=+23.9\left(c=2, \mathrm{H}_{2} \mathrm{O}\right)\right]$. The salt was dissolved in water $(5 \mathrm{~mL})$ basified with $\mathrm{NaOH}(1.22 \mathrm{~g})$ solubilized in water $(5 \mathrm{~mL})$ and then saturated with $\mathrm{K}_{2} \mathrm{CO}_{3}(3$ g). The free base was extracted with ether $(20 \mathrm{~mL} \times 6)$. The dried extracts $\left(\mathrm{Na}_{2} \mathrm{SO}_{4}\right)$ were concentrated to give $(1 R)-6 \beta$ methoxytropinone (-)-7 as a colorless oil $(1.13 \mathrm{~g}, 6.7 \mathrm{mmol})$ that solidified on standing: $\mathrm{mp} 42{ }^{\circ} \mathrm{C}$ (lit. $\mathrm{mp} 43-45{ }^{\circ} \mathrm{C}$ ) $;{ }^{23}$ $[\alpha]^{20}{ }_{\mathrm{D}}=-22.79\left(c=0.5, \mathrm{H}_{2} \mathrm{O}\right)\left[\mathrm{lit}^{23}[\alpha]^{20}{ }_{\mathrm{D}}=+23.9(c=2\right.$, $\left.\mathrm{H}_{2} \mathrm{O}\right)$ ]. The mother liquors from above were evaporated to dryness, dissolved in water, treated with $\mathrm{K}_{2} \mathrm{CO}_{3}$ until $\mathrm{pH} 8$, and extracted with diethyl ether $(20 \mathrm{~mL} \times 6)$. The dried extracts $\left(\mathrm{Na}_{2} \mathrm{SO}_{4}\right)$ were evaporated to give a colorless oil (1.44 $\mathrm{g}, 8.51 \mathrm{mmol})$. Treatment of the oil with (+)-L-tartaric acid $(1.13 \mathrm{~g}, 8.51 \mathrm{mmol})$ gave a salt which was recrystallized and converted to the free base as described for the $R$ isomer. The salt $(1.81 \mathrm{~g}, 5.7 \mathrm{mmol})$ had mp $126-127^{\circ} \mathrm{C}$ and $[\alpha]^{20}{ }_{\mathrm{D}}=+22.06$ $\left(c=0.5, \mathrm{H}_{2} \mathrm{O}\right)$. The (1S)-6 $\beta$-methoxytropinone (+)-7 obtained had $[\alpha]^{20} \mathrm{D}=+23.8\left(c=0.5, \mathrm{H}_{2} \mathrm{O}\right)$.

General Procedures for the Synthesis of Target Compounds. (1R)-3 $\alpha$-[Bis(4-fluorophenyl)methoxy]-6 $\beta$-methoxy-8-methyl-8-aza-bicyclo[3.2.1] octane (-)-(6c). The $6 \beta$ methoxytropine (+)-(8) $(130 \mathrm{mg}, 0.759 \mathrm{mmol}), 4,4^{\prime}$-difluorobenzhydrol (335 mg, $1.52 \mathrm{mmol})$, and $p$-toluenesulfonic acid monohydrate $(216 \mathrm{mg}, 1.13 \mathrm{mmol})$ were solubilized in benzene $(30 \mathrm{~mL})$ and placed in a flask fitted with a Dean-Stark apparatus. The reaction mixture was heated to reflux for 18 h. Additional 4,4'-difluorobenzhydrol ( $167 \mathrm{mg}, 0.759 \mathrm{mmol})$ and $p$-toluenesulfonic acid monohydrate $(36 \mathrm{mg}, 0.19 \mathrm{mmol})$ were added, and the reaction mixture was refluxed for other $6 \mathrm{~h}$. Solvent was removed in vacuo and the residue dissolved in $\mathrm{H}_{2} \mathrm{O}(20 \mathrm{~mL})$, neutralized with $\mathrm{NH}_{4} \mathrm{OH}$ to $\mathrm{pH} 9$, and extracted with $\mathrm{CH}_{2} \mathrm{Cl}_{2}(15 \mathrm{~mL} \times 3)$. The combined extracts were dried $\left(\mathrm{Na}_{2} \mathrm{SO}_{4}\right)$ and concentrated to dryness. The residue was purified by flash chromatography $\left(\mathrm{CHCl}_{3}: \mathrm{MeOH} 95: 5\right)$ to give $100 \mathrm{mg}(35 \%)$ of title compound as a pale yellow oil. $\mathrm{HCl}$ salt $\mathrm{mp} 65^{\circ} \mathrm{C} ;[\alpha]^{20}{ }_{\mathrm{D}}=-5.7\left(c=0.29, \mathrm{H}_{2} \mathrm{O}\right)$. Anal. $\left(\mathrm{C}_{22} \mathrm{H}_{25} \mathrm{~F}_{2} \mathrm{NO}_{2}\right)$ : $\mathrm{C}, \mathrm{H}, \mathrm{N}$.

(1R)-3 $\alpha$-Diphenylmethoxy-6 $\beta$-methoxy-8-methyl-8-azabicyclo[3.2.1]octane (-)-(6a). As described for (-)-(6c) starting from (+)-8 and benzhydrol. Colorless oil (42\% yield); $\mathrm{HCl}$ salt mp $191{ }^{\circ} \mathrm{C} ;[\alpha]^{20}{ }_{\mathrm{D}}=-7.9\left(c=0.49, \mathrm{H}_{2} \mathrm{O}\right)$. Anal. $\left(\mathrm{C}_{22} \mathrm{H}_{27^{-}}\right.$ $\left.\mathrm{NO}_{2}\right): \mathrm{C}, \mathrm{H}, \mathrm{N}$.

(1R)-3 $\alpha$-[(4-Chlorophenyl)phenyl-methoxy]-6 $\beta$-methoxy8-methyl-8-aza-bicyclo[3.2.1]octane (-)-(6b). As described for (-)-(6c) starting from (+)-8 and 4-chlorobenzhydrol. Colorless oil $(46 \%$ yield $) ;[\alpha]^{20}{ }_{\mathrm{D}}=-0.5(c=0.9, \mathrm{MeOH})$. Anal. $\left(\mathrm{C}_{22} \mathrm{H}_{27} \mathrm{ClNO}_{2}\right)$ : C, H, N.

(1S)-3 $\alpha$-[Bis(4-fluorophenyl)methoxy]-6 $\beta$-methoxy-8methyl-8-aza-bicyclo[3.2.1]octane (+)-(6c). As described for $(-)$-(6c) starting from (-)-8 and 4,4'-difluorobenzhydrol. Yield $46 \%$. $\mathrm{HCl}$ salt $\mathrm{mp} 65^{\circ} \mathrm{C} ;[\alpha]^{20}{ }_{\mathrm{D}}=+6.5\left(c=0.35, \mathrm{H}_{2} \mathrm{O}\right)$. Anal. $\left(\mathrm{C}_{22} \mathrm{H}_{25} \mathrm{~F}_{2} \mathrm{NO}_{2}\right)$ : C, $\mathrm{H}, \mathrm{N}$.

(1S)-3 $\alpha$-Diphenylmethoxy-6 $\beta$-methoxy-8-methyl-8-azabicyclo[3.2.1]octane (+)-(6a). As described for (-)-(6c) starting from (-)-8 and benzhydrol. Yield $42 \%$. $\mathrm{HCl}$ salt $\mathrm{mp} 190$ ${ }^{\circ} \mathrm{C} ;[\alpha]{ }^{20}{ }_{\mathrm{D}}=+9.1\left(c=0.45, \mathrm{H}_{2} \mathrm{O}\right)$. Anal. $\left(\mathrm{C}_{22} \mathrm{H}_{27} \mathrm{NO}_{2}\right): \mathrm{C}, \mathrm{H}$, N.

(1S)-3 $\alpha$-[(4-Chlorophenyl)phenylmethoxy]-6 $\beta$-methoxy8-methyl-8-aza-bicyclo[3.2.1] for (-)-(6c) starting from (-)-8 and 4-chloro-benzhydrol. Yield $66 \% ;[\alpha]^{20}{ }_{\mathrm{D}}=+0.8(c=1.0, \mathrm{MeOH})$. Anal. $\left(\mathrm{C}_{22} \mathrm{H}_{27} \mathrm{ClNO}_{2}\right): \mathrm{C}$, $\mathrm{H}, \mathrm{N}$.

$( \pm)$-3 $\alpha$-Diphenylmethoxy-6 $\beta$-methoxymethoxy-8-methyl-8-aza-bicyclo[3.2.1]octane (5a). A solution of the alcohol $14(250 \mathrm{mg}, 1.08 \mathrm{mmol})$, dry tributylamine $(0.23 \mathrm{~mL}, 1.2$ equiv), and benzhydryl chloride ( $0.35 \mathrm{~mL}, 2$ equiv) in dry dimethylformamide $(7 \mathrm{~mL})$ was refluxed for $8 \mathrm{~h}$ under $\mathrm{N}_{2}$ atmosphere. The dark solution was concentrated in vacuo to about one-half of its original volume, diluted with $\mathrm{H}_{2} \mathrm{O}(20 \mathrm{~mL})$, and extracted with diethyl ether $(50 \mathrm{~mL} \times 3)$; the combined organic layers were washed with saturated aqueous $\mathrm{Na}_{2} \mathrm{CO}_{3}$ $(30 \mathrm{~mL})$ and brine and dried over anydrous $\mathrm{Na}_{2} \mathrm{SO}_{4}$. The crude product obtained after solvent distillation was purified by flash chromatography to afford $\mathbf{5 a}$ as a colorless oil (210 mg, $42 \%$ ): $R_{\mathrm{f}} 0.3$ (AcOEt:MeOH: $\mathrm{NH}_{4} \mathrm{OH}$ 5:1:0.1). MALDI-TOF MS: $[\mathrm{MH}]^{+}$ 368. Anal. $\left(\mathrm{C}_{23} \mathrm{H}_{29} \mathrm{NO}_{3}\right)$ : C, $\mathrm{H}, \mathrm{N}$.

( \pm )-3 $\alpha-[$ (4-Chlorophenyl)phenylmethoxy $]-6 \beta$-methoxymethoxy-8-methyl-8-aza-bicyclo[3.2.1] ]octane (5b). As described for 5a by means of 4-chlorobenzhydryl chloride. White solid (44\% yield): $\mathrm{mp} 151-153^{\circ} \mathrm{C} ; R_{\mathrm{f}} 0.5$ (AcOEt:MeOH: 
$\mathrm{NH}_{4} \mathrm{OH}$ 5:1:0.1). MALDI-TOF MS: $[\mathrm{MH}]^{+}$402.9. Anal. $\left(\mathrm{C}_{23} \mathrm{H}_{28^{-}}\right.$ $\left.\mathrm{ClNO}_{3}\right): \mathrm{C}, \mathrm{H}, \mathrm{N}$.

$( \pm)-3 \alpha$-[Bis (4-fluorophenyl)methoxy]-6 $\beta$-methoxymethoxy-8-methyl-8-aza-bicyclo[3.2.1]octane (5c). As described for $\mathbf{5 a}$ by means of 4,4'-difluorobenzhydryl chloride. White solid (49\% yield): $\mathrm{mp} 194-196{ }^{\circ} \mathrm{C} ; R_{\mathrm{f}} 0.45$ (AcOEt: $\mathrm{MeOH}: \mathrm{NH}_{4} \mathrm{OH}$ 5:1:0.1). MALDI-TOF MS: $[\mathrm{MH}]^{+}$404. Anal. $\left(\mathrm{C}_{23} \mathrm{H}_{27} \mathrm{~F}_{2} \mathrm{NO}_{3}\right)$ : C, H, N.

( \pm )-3 $\alpha$-Diphenylmethoxy-8-methyl-8-aza-bicyclo[3.2.1]octan-6 $\beta$-ol (5d). Forty milligrams $(0.108 \mathrm{mmol})$ of $\mathbf{5 a}$ was dissolved in $\mathrm{MeOH}(3 \mathrm{~mL})$, and $100 \mu \mathrm{L}$ of $37 \% \mathrm{HCl}$ was added at $0{ }^{\circ} \mathrm{C}$. The reaction was stirred at $60{ }^{\circ} \mathrm{C}$ until the starting material completely disappeared (TLC AcOEt:MeOH: $\mathrm{NH}_{4} \mathrm{OH}$ $3: 1: 0.1$ ). After $3 \mathrm{~h}$, the reaction mixture was basified with saturated $\mathrm{NaHCO}_{3}(5 \mathrm{~mL})$ and extracted with $\mathrm{CH}_{2} \mathrm{Cl}_{2}(10 \mathrm{~mL}$ $\times 3$ ), and the combined organic layers were washed with brine and dried over anydrous $\mathrm{Na}_{2} \mathrm{SO}_{4}$. The crude product was purified by flash chromatography (AcOEt:MeOH: $\mathrm{NH}_{4} \mathrm{OH} 2: 1$ : $0.1)$ to afford the desired alcohol $\mathbf{5 d}$ as a colorless oil (33 $\mathrm{mg}$, 94\%). $R_{\mathrm{f}} 0.2$ (AcOEt:MeOH:NH $\mathrm{NH}_{4} \mathrm{OH}$ 3:1:0.1). MALDI-TOF MS: $[\mathrm{MH}]^{+}$324.8. Anal. $\left(\mathrm{C}_{21} \mathrm{H}_{25} \mathrm{NO}_{2}\right)$ : C, H, N.

( \pm -3 $\alpha$-[(4-Chlorophenyl)phenylmethoxy]-8-methyl-8aza-bicyclo[3.2.1]octan-6 $\beta$-ol (5e). As described for 5d starting from $\mathbf{5 b}$. The crude product was purified by flash chromatography (AcOEt:MeOH: $\mathrm{NH}_{4} \mathrm{OH}$ 3:1:0.1, $R_{\mathrm{f}}$ 0.3) to afford a white solid (95\% yield): $\mathrm{mp} 242-244{ }^{\circ} \mathrm{C}$. MALDI-TOF MS: $[\mathrm{MH}]^{+}$359. Anal. $\left(\mathrm{C}_{21} \mathrm{H}_{24} \mathrm{ClNO}_{2}\right)$ : C, H, N.

$( \pm)$-3 $\alpha$-[Bis-(4-fluorophenyl)methoxy]-8-methyl-8-azabicyclo[3.2.1] loctan-6 $\beta$-ol (5f). As described for 5d starting from 5c. The crude product was purified by flash chromatography (AcOEt:MeOH: $\mathrm{NH}_{4} \mathrm{OH}$ 5:1:0.1) to afford a white solid (94\% yield): mp $228-231{ }^{\circ} \mathrm{C} ; R_{\mathrm{f}} 0.25$ (AcOEt:MeOH: $\mathrm{NH}_{4} \mathrm{OH}$ 3:1:0.1). MALDI-TOF MS: $[\mathrm{MH}]^{+} 360$. Anal. $\left(\mathrm{C}_{21} \mathrm{H}_{23} \mathrm{~F}_{2} \mathrm{NO}_{2}\right)$ : $\mathrm{C}, \mathrm{H}, \mathrm{N}$.

$( \pm)$-3 $\alpha$-[Bis(4-fluorophenyl)methoxy]-6 $\alpha$-methoxy-8methyl-8-aza-bicyclo[3.2.1] loctane (5g). As described for (-)-(6c) starting from 20a. Colorless oil (yield. 39\%). MALDITOF MS: $[\mathrm{MH}]^{+}$374. Anal. $\left(\mathrm{C}_{22} \mathrm{H}_{25} \mathrm{~F}_{2} \mathrm{NO}_{2}\right)$ : C, H, N.

( \pm )-3 $\alpha$-[Bis (4-fluorophenyl)methoxy]-6 $\alpha$-methoxymethoxy-8-methyl-8-aza-bicyclo[3.2.1] octane (5h). As described for $\mathbf{5 a}$ from compound $\mathbf{2 0 b}$ by means of $4,4^{\prime}$ difluorobenzhydryl chloride. Colorless oil ( $42 \%$ yield): $R_{\mathrm{f}} 0.5$ (AcOEt:MeOH: $\mathrm{NH}_{4} \mathrm{OH}$ 5:1:0.1). MALDI-TOF MS: $[\mathrm{MH}]^{+} 404$ Anal. $\left(\mathrm{C}_{23} \mathrm{H}_{27} \mathrm{~F}_{2} \mathrm{NO}_{3}\right)$ : C, H, N.

( \pm )-3 $\alpha$-[Bis-(4-fluorophenyl)methoxy]-8-methyl-8-azabicyclo[3.2.1] octan-6 $\alpha-o l$ (5i). As described for 5d starting from $\mathbf{5 h}$. The crude product was purified by flash chromatography (AcOEt:MeOH: $\mathrm{NH}_{4} \mathrm{OH}$ 6:1:0.1) to afford a white solid ( $40 \%$ yield): $\mathrm{mp} 214-216{ }^{\circ} \mathrm{C} ; R_{\mathrm{f}} 0.35$ (AcOEt: $\mathrm{MeOH}: \mathrm{NH}_{4} \mathrm{OH}$ 3:1:0.1). MALDI-TOF MS: $[\mathrm{MH}]^{+}$361. Anal. $\left(\mathrm{C}_{21} \mathrm{H}_{23} \mathrm{~F}_{2} \mathrm{NO}_{2}\right)$ : $\mathrm{C}, \mathrm{H}, \mathrm{N}$.

( \pm )-6 $\alpha$-[Bis-(4-fluorophenyl)methoxy]-8-methyl-8-azabicyclo[3.2.1] ]octane (24). As described for 5 a by means of 4,4'-difluorobenzhydryl chloride and alcohol 23. White solid (57\% yield): $\mathrm{mp} 250-253{ }^{\circ} \mathrm{C} ; R_{\mathrm{f}} 0.45$ (AcOEt: $\mathrm{MeOH}: \mathrm{NH}_{4} \mathrm{OH}$ 5:1:0.1). MALDI-TOF MS: $[\mathrm{MH}]^{+} 344$. Anal. $\left(\mathrm{C}_{21} \mathrm{H}_{23} \mathrm{~F}_{2} \mathrm{NO}\right)$ : $\mathrm{C}$, $\mathrm{H}, \mathrm{N}$.

( \pm )-6 $\beta$-[Bis-(4-fluorophenyl)methoxy]-8-methyl-8-azabicyclo[3.2.1] octane (25). As described for 5a by means of 4,4'-difluorobenzhydryl chloride and alcohol $\mathbf{2 1}$. White solid (62\% yield): mp $224-226{ }^{\circ} \mathrm{C} ; R_{\mathrm{f}} 0.4$ (AcOEt: $\mathrm{MeOH}: \mathrm{NH}_{4} \mathrm{OH}$ 5:1:0.1). MALDI-TOF MS: $[\mathrm{MH}]^{+} 344$. Anal. $\left(\mathrm{C}_{21} \mathrm{H}_{23} \mathrm{~F}_{2} \mathrm{NO}\right)$ : $\mathrm{C}$, $\mathrm{H}, \mathrm{N}$.

Acknowledgment. This work was supported in part by the Ministero dell'Università e della Ricerca Scientifica e Tecnologica, Rome, Italy.

Supporting Information Available: Experimental details for synthesis, characterization, and biological evaluation for all new compounds listed in Schemes 1-4 and Table 1. X-ray crystallographic data in CIF file for compound (-)-10. This material is available free of charge via Internet at http:// pubs.acs.org.

\section{References}

(1) Carrol, F. I; Howell, L. L; Kuhar, M. J. Pharmacoterapies for Treatment of Cocaine Abuse: Preclinical Aspects. J. Med. Chem. 1999, 42, 2721-2736, and references therein.

(2) Smith, M. P.; Hoepping, A.; Johnson, K. M.; Trzcinska, M.; Kozikowski, A. P. Dopaminergic agents for the treatment of cocaine abuse. Drug. Discovery Today 1999, 4, 322-332, and references therein.

(3) Kuhar, M. J.; Ritz, M. C.; Boja, J. W. The dopamine hypothesis of the reinforcing properties of cocaine. Trends Neurosci. 1991, 14, 299-301.

(4) Madras, B. K.; Miller, G. M.; Meltzer, P. C.; Brownell, A. L.; Fischmann, A. J. Molecular and regional targets of cocaine in primate brain: liberation from prosaic view. Addiction Biol. 2000, 5, 351-359.

(5) Newman, A. H.; Kulkarni, S. Probes for dopamine transporter: new leads toward a cocaine-abuse therapeutic: a focus on analogues of benztropine and rimcazol. Med. Res. Rev. 2002, 22 , 429-464, and references therein.

(6) Meltzer, P. C.; Blundell, P.; Madras, B. K. Structure-activity relationship of inhibition of the dopamine transporter by 3-arylbicyclo[3.2.1] octanes. Med. Chem. Res. 1998, 8, 12-34.

(7) Meltzer, P. C.; Wang, B.; Chen, Z.; Blundell, P.; Jayaraman, M.; Gonzales, M. D.; George, C.; Madras, B. K. Synthesis of 6- and 7-hydroxy-8-bicyclo[3.2.1]octanes and their binding affinity for the dopamine and serotonin transporter. J. Med. Chem. 2001, $44,2619-2635$

(8) Lomenzo, S. A.; Izenwasser, S.; Katz, J. L.; Terry, P. D.; Zhu, N.; Klein, C. L.; Trudell, M. L. Synthesis, structure, dopamine transporter affinity and dopamine uptake inhibition of 6-alkyl3-benzyl-2-[(methoxycarbonyl)methyl]tropane derivatives. J. Med. Chem. 1997, 40, 4406-4414.

(9) Prakash, K. R. C.; Araldi, G. L.; Smith, M. P.; Zhang, M.; Johnson, K. M.; Kozikowski, A. P. Synthesis and biological activity of new 6 - and 7 -substituted $2 \beta$-butyl-3-phenyltropanes as ligands for the dopamine transporter. Med. Chem. Res. 1998, $8,43-58$.

(10) Chen, Z.; Meltzer, P. C. Synthesis of 6- or 7-hydroxy and 6- or 7-methoxy tropanes. Tetrahedron Lett. 1997, 38, 1121-1124.

(11) Simoni, D.; Stoelwinder, J.; Kozikowski, A. P.; Johnson, K. M.; Bergmann, J. S.; Ball, R. G. Methoxylation of cocaine reduces binding affinity and produces compounds of differential binding and dopamine uptake inhibitory activity: discovery of a weak cocaine 'antagonist'. J. Med. Chem. 1993, 36, 3975-3977.

(12) Simoni, D.; Roberti, M.; Andrisano, M.; Manferdini, M.; Rondanin, R.; Kozikowski, A. P. Concise enantioselective synthesis and attribution of the absolute configuration of two-carbon bridge methoxylated cocaines and pseudococaines. J. Org. Chem. 1998, $63,4834-4837$

(13) Kozikowski, A. P.; Simoni, D.; Manfredini, S.; Roberti, M. Stoelwinder, J. Synthesis of the 6- and 7-hydroxylated cocaines and pseudococaines. Tetrahedron Lett. 1996, 37, 5333-5336.

(14) Meltzer, P. C.; Liang, A. Y.; Madras, B. K. The discovery of an unusually selective and novel cocaine analogue: difluoropine. Synthesis and inhibition of binding at cocaine recognition sites. J. Med. Chem. 1994, 37, 2001-2010.

(15) Meltzer, P. C.; Liang, A. Y ; Madras, B. K. 2-Carbomethoxy-3 (diarylmethoxy)-1 $\alpha H, 5 \alpha H$-tropane analogues: synthesis and inhibition of binding at the dopamine transporter and comparison with piperazine of the GBR series. J. Med. Chem. 1996, 39, 371-379.

(16) Van der Zee, P.; Hespe, W. Interaction between substituted 1-[2(diphenylmethoxy)ethyl] piperazines and dopamine receptors. Neuropharmacology 1985, 24, 1171-1174.

(17) Newman, A. H.; Agoston, G. E. Novel benztropine[3 $\alpha$-(diphenylmethoxy)tropanel analogs as probes for the dopamine transporter. Curr. Med. Chem. 1998, 5, 301-315.

(18) Newman, A. H.; Robarge, M. J.; Izenwasser, S.; Kline, R. H. A comparative molecular field analysis (CoMFA) study of novel ring substituted $3 \alpha$-(diphenylmethoxy)tropane analogues at the dopamine transporter. J. Med. Chem. 1999, 42, 3502-3509.

(19) Zou, M. F.; Kopajtic, T.; Katz, J. L.; Newman, A. H. Structureactivity relationship of $(S)-2 \beta$-substituted-3 $\alpha$-(bis[4-fluorophenyl]methoxy)tropanes and $(R)-2 \beta$-substituted-3 $\beta$-(3,4-dichlorophenyl)tropanes at the dopamine transporter. J. Med. Chem. 2003, $46,2908-2916$

(20) Zou, M. F.; Agoston, G. E.; Belov, Y.; Kopajtic, T.; Katz, J. L.; Newman, A. H. Enantioselective synthesis of $S$-(+)-2 $\beta$-carboalkoxy-3 $\alpha$-[bis(4-fluorophenyl)methoxy]tropanes as novel probes for the dopamine transporter. Bioorg. Med. Chem. Lett. 2002 $12,1249-1252$

(21) Acri, J. B.; Siedleck, B. K.; Witkin, J. M. Effects of benztropine on behavioral and toxic effects of cocaine: comparison with atropine and the selective dopamine uptake inhibitor 1-[2(diphenylmethoxy)ethyl]-4-(3-phenylpropyl)-piperazine. J. Pharmacol. Exp. Ther. 1996, 277, 198-206. 
(22) Simoni, D.; Roberti, M.; Rondanin, R.; Baruchello, R.; Rossi, M.; Invidiata, F. P.; Merighi, S.; Varani, K.; Gessi, S.; Borea, P. A.; Marino, S.; Cavallini, S.; Bianchi, C.; Siniscalchi, A. Effects of two-carbon bridge methoxylation of benztropine: discovery of novel chiral ligands for the dopamine transporter. Bioorg. Med. Chem. Lett. 2001, 11, 823-827.

(23) Fodor, G.; Soti, F. The stereochemistry of the tropane alkaloids XVII. Correlation of valeroidine with $(S)-(-)$-methoxysuccinic acid and of mono- and ditigloyltropane-3,6-diol with its $(R)-(+)-$ enantiomer. J. Chem. Soc. 1965, 6830-6833.

(24) Grundt, P.; Kopajtic, T. A.; Katz, J. L.; Newman, A. H. The effect of 6 -substituted- $4^{\prime}, 4^{\prime \prime}$-difluorobenztropine on monoamine transporters and the muscarinic M1 receptor. Bioorg. Med. Chem. Lett. 2004, 14, 3295-3298.

JM0490235 